September 2000 • NREL/TP-550-28872

\title{
A Market Assessment of Residential Grid-Tied PV Systems in Colorado
}

\section{Executive Summary}

\author{
Barbara C. Farhar, Ph.D. \\ Timothy C. Coburn, Ph.D.
}

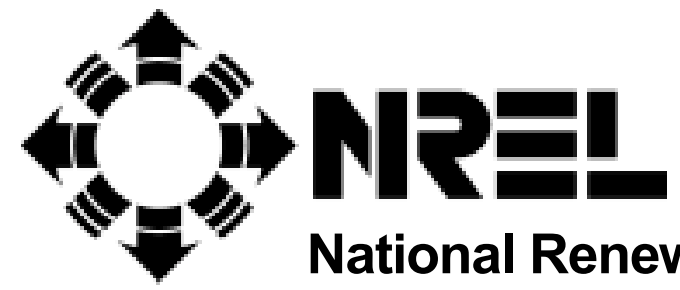

1617 Cole Boulevard

Golden, Colorado 80401-3393

NREL is a U.S. Department of Energy Laboratory

Operated by Midwest Research Institute $\bullet$ Battelle $\bullet$ Bechtel

Contract No. DE-AC36-99-G010337 


\section{A Market Assessment of Residential Grid-Tied PV Systems in Colorado}

\section{Executive Summary}

Barbara C. Farhar, Ph.D.

Timothy C. Coburn, Ph.D.

Prepared under Task No. PV00.8201

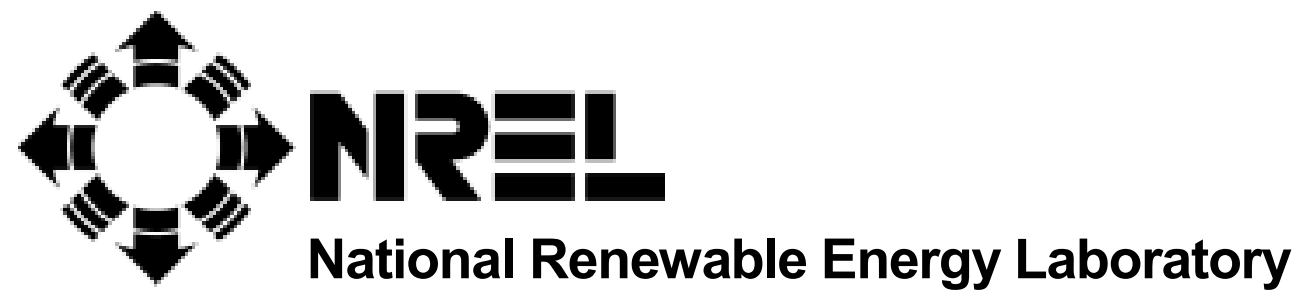

1617 Cole Boulevard

Golden, Colorado 80401-3393

NREL is a U.S. Department of Energy Laboratory

Operated by Midwest Research Institute $\bullet$ Battelle $\bullet$ Bechtel

Contract No. DE-AC36-99-G010337 


\section{NOTICE}

This report was prepared as an account of work sponsored by an agency of the United States government. Neither the United States government nor any agency thereof, nor any of their employees, makes any warranty, express or implied, or assumes any legal liability or responsibility for the accuracy, completeness, or usefulness of any information, apparatus, product, or process disclosed, or represents that its use would not infringe privately owned rights. Reference herein to any specific commercial product, process, or service by trade name, trademark, manufacturer, or otherwise does not necessarily constitute or imply its endorsement, recommendation, or favoring by the United States government or any agency thereof. The views and opinions of authors expressed herein do not necessarily state or reflect those of the United States government or any agency thereof.

Available electronically at http://www.doe.gov/bridge

Available for a processing fee to U.S. Department of Energy

and its contractors, in paper, from:

U.S. Department of Energy

Office of Scientific and Technical Information

P.O. Box 62

Oak Ridge, TN 37831-0062

phone: 865.576.8401

fax: 865.576.5728

email: reports@adonis.osti.gov

Available for sale to the public, in paper, from:

U.S. Department of Commerce

National Technical Information Service

5285 Port Royal Road

Springfield, VA 22161

phone: 800.553.6847

fax: 703.605.6900

email: orders@ntis.fedworld.gov

online ordering: http://www.ntis.gov/ordering.htm

Printed on paper containing at least $50 \%$ wastepaper, including $20 \%$ postconsumer waste 


\section{Preface}

This report is the Executive Summary of a 200-page technical report entitled A Market Assessment of Residential Grid-Tied PV Systems in Colorado by Barbara C. Farhar and Timothy C. Coburn, NREL/TP-550-25283.

The Colorado Office of Energy Conservation and Management (OEC) and the National Renewable Energy Laboratory's (NREL's) STEP-2 Program partnered to fund this research. The OEC funded the research at the University of Colorado, Boulder. Program managers were Marc Roper, then of OEC, and Carol Tombari, then of NREL's State and Local Programs Office. Professor Dennis Mileti, chair, and Steve Graham, staff assistant, Department of Sociology, University of Colorado, Boulder, provided encouragement and administrative support to the project. Ron Judkoff and Sheila Hayter of NREL's Center for Buildings and Thermal Systems extended themselves in support of the project. Many colleagues in the energy and utility communities expressed interest in the study.

The authors would like to acknowledge other key contributors to the quantitative phase of this study:

Jan Buhrmann, Ph.D., U.S. Environmental Protection Agency, Denver

Elizabeth Sheff, graduate student, Department of Sociology, University of Colorado, Boulder

K. L. Berry, Matrix International, consultant, data analysis

Direct Marketing Designs, Inc., and The Polk Company, sampling frame, sampling, and mailing services

Alexander's Data Services, Inc., data entry and cleaning

David Lillie, User Interface Services, data base integrity

Rochelle Watters, NREL, project coordination and support, manuscript preparation

Erica Henningsen, NREL, manuscript preparation

University of Colorado Printing Services, printing services

University of Colorado Mail Room, mail handling

The authors acknowledge David Crawford, Kay Vernon, and Susan Sczepanski for editing and manuscript preparation. 


\section{Executive Summary}

This research began in response to a decision by the Colorado Governor's Office of Energy Conservation and Management (OEC) and Colorado utility companies to consider making residential grid-tied photovoltaic (PV) systems available in Colorado. The idea was to locate homeowners willing to pay the costs of grid-tied PV (GPV) systems without batteriesC $\$ 8,000$ or $\$ 12,000$ for a 2- or 3-kilowatt (kW) system, respectively, in 1996. These costs represented two-thirds of the actual installed cost of $\$ 6$ per watt at that time and assumed the remainder would be subsidized.

The National Renewable Energy Laboratory (NREL) and OEC partnered to conduct a market assessment for GPV technology in Colorado. The study encompassed both qualitative and quantitative phases. The qualitative phase focused on identifying residential customers willing to pay certain amounts for a GPV system and to explore their reasons for wanting to become involved with the technology. The quantitative phase was designed to gather data on GPV from a probability sample of Colorado homeowners. The ultimate objective of the quantitative phase was to develop estimates of the size of the GPV market among Colorado homeowners.

Owning homes with GPV systems to power them is a new idea-an innovation. Hence, the diffusion-ofinnovations tradition - an established theory of social and technological change - formed the basis for this research on homeowner response to GPV technology. The adoption of innovations, such as using residential GPV to provide all or part of a home's electricity, is a process occurring over time. Much research has focused on the perceived attributes of innovations that affect their rate of adoption, and on the characteristics of innovation adopters. Attributes determining how quickly innovations will spread include: relative advantage; compatibility with social values, past experiences, and needs; complexity; trialability; and observability.

Researchers have generally categorized populations into five types according to how quickly they adopt innovations. The leading edge of adopters is called "innovators" (about $2.5 \%$ of a population). Next, a group of about $13.5 \%$ is defined as "early adopters." Early adopters are also frequently "opinion leaders" who serve as an important social catalyst to shift the penetration of innovations from the select few to the "early majority" $(34 \%)$.

Using this model as a foundation, the quantitative phase of the present study was designed to measure perception about GPV, and to establish homeowner characteristics (such as demographics, environmental values, and opinion leadership) relevant to potential early adoption of the technology.

\section{Research Approach}

The qualitative phase of this study resulted in the report: Public Response to Residential Grid-Tied PV Systems in Colorado: A Qualitative Market Assessment (Farhar and Buhrmann 1998). The qualitative work greatly supported and informed the quantitative phase of the study, for which two specific questionnaires were developed: one on grid-tied PV systems and the other pertaining to renewable energy, environmental concerns, and utility restructuring. The results of the second questionnaire are reported in Farhar and Coburn (1999). In all, the first questionnaire was administered as a conventional mail survey to a probability sample of 6,088 Colorado single-family homeowners drawn at random from across the state. The survey was designed in such a way as to permit categorization of homeowners in Colorado in the various stages of the GPV adoptiondecision process, thus permitting estimates of market sizes. The study's dependent variables included 
willingness to pay for GPV, favorability toward the idea of using GPV on one's own home, and likelihood of seeking further information about GPV.

A total of 3,001 respondents completed questionnaires. Because the sampling frame unavoidably contained undeliverable addresses, townhouse owners, and others not qualified to be respondents, the number of qualified respondents was lower than the number of questionnaires mailed. The overall response rate was approximately $60 \%$. Findings are generalizable to all Colorado single-family owner-occupied households (some 624,000 in all).

Such a large sample was used in order to capture an anticipated small "signal" from homeowners interested in purchasing GPV systems; that is, the prior assumption was that only a few homeowners would be interested in GPV purchase at today's market prices. In fact, the findings indicate a much higher positive response to grid-tied PV than anticipated, despite the costs of the technology presented in the questionnaire.

\section{Descriptive Findings: Knowledge, Favorability, Benefits, Barriers, and Information}

A majority of $68 \%$ of survey respondents favor GPV being made more widely available to Colorado residents. Respondents know little about GPV, as would be expected. While familiarity and favorability toward GPV are somewhat correlated, there is clearly more favorability than familiarity. At first blush, respondents tend to favor GPV without knowing much about it.

Important perceived benefits of GPV make it seem advantageous compared with conventional energy sources. A bare majority of homeowners (52\%) know that coal is Colorado's primary power source, making it less likely that homeowners would attribute as many environmental advantages to PV ownership as they would if they were more aware of the extent of coal use. The survey asked about the importance of 23 potential benefits of GPV. The highest-scoring benefits were divided between long-term environmental benefits, including conserving natural resources, and homeowner financial benefits, including reducing electricity bills right away and long-term savings. Factor analysis resulted in three major dimensions: environmental benefits, financial advantages, and pacesetting advantages of adopting GPV. PV marketing messages should cover these three themes.

The survey presented respondents with 18 potential concerns regarding, or potential barriers to, PV system purchase. Barriers could reduce the perceived relative advantage of buying and owning a GPV system. Initial system cost and maintenance costs are key concerns. Homeowners also care about the reputability of PV manufacturers and vendors. Factor analysis resulted in two components: (1) feasibility of PV systems and reliability of PV providers, and (2) local conditions that might be problematic, such as codes or covenants prohibiting PV adoption, what friends and neighbors might say, or the amount of space needed at one's home for a PV system.

The survey explored 15 potential information needs and 24 information sources concerning GPV system purchase. Homeowners need information about concerns and benefits of PV ownership. The top-scoring information needs were savings on utility bills; amount of electricity the PV system will produce; and battery costs, maintenance, and disposal. Factor analysis was performed on the information-needs variables, resulting in three important components: PV product available to customers, financial aspects of PV system purchase and ownership, and benefits of PV use to the community and the world. GPV system marketers should address each of these major themes. 
The utility company is the highest rated potential supplier of GPV systems and, for that reason alone, the utility company is an important, even authoritative, information source on GPV. The study's query on information sources had two parts: (1) individual, groups, and organizational sources of information on GPV, and (2) information channels, such as broadcast media or workshops. Both were factor analyzed, with the following results. The highest rated sources of PV information were people who already own PV systems and utility companies. PV manufacturers and suppliers were also a somewhat highly rated source. Three dimensions of information sources were defined: (1) government agencies, (2) local building businesses (such as home builders, local contractors, and home supply stores), and (3) friends and other trusted sources (including environmental organizations).

The highest rated kinds of information are those which give people a chance to see, touch, and experience PV technology, and to talk with those who have already lived with a PV system. Other than these sources, channels requiring people to spend time and money are less highly rated. Print media are more highly rated than broadcast media. These information channels appear to fit well with the technological nature of GPV systems.

\section{Descriptive Findings: Product Attributes}

GPV's feasibility for use now is an important attribute. Homeowners rate PV system warranties and durablity as very important. They rate financial incentives, such as rebates or tax credits, to help them purchase a system as highly important, as well as battery options to provide power during a power outage. The potential to keep computers running during an outage appears to be an important attribute in addition to other basic necessities such as heat, refrigeration, and lighting.

\section{Descriptive Findings: Willingness to Pay for Residential GPV and Favorability to Using GPV}

Data were obtained on four possible scenarios related to obtaining a GPV system, including one scenario that involved no added cost. Larger percentages of respondents than expected are hypothetically interested in paying for various-sized PV systems, with the most interest expressed in systems providing half or all of a household's electricity. About three-quarters of respondents say they would, at least hypothetically, be interested in paying at least something more per month for grid-tied PV. Eleven percent prefer a PV system that provides $100 \%$ of a household's electricity at a one-time cost of between $\$ 14,000$ and $\$ 28,000$, depending on how much electricity the household uses. Approximately $40 \%$ of Colorado single-family homeowners comprise the minimum market for a no-added-cost grid-tied PV system.

When asked about subsidies for GPV, more than one-third of this self-described politically conservative sample call for a federal income tax credit to support GPV. Twelve percent say they are opposed to all subsidies. Seventy percent say they would be likely to purchase a subsidized GPV system whose net cost is no higher than what they are currently paying for electricity.

The most popular financing option for GPV system purchase is to pay for a system through the utility bill. Equally popular as second choice are financing through a home mortgage or by paying a PV manufacturer or supplier. 
After responding to several questions on potentially positive and negative aspects of GPV ownership, respondents were asked to consider the idea of using PV on their own homes. A majority of $57 \%$ indicate favorability; $25 \%$ are neutral; $11 \%$ are unfavorable; and $6 \%$ don't know. Initially favorable respondents tend to remain favorable to the idea of GPV ownership, even after considering realistic market costs.

\section{Segmenting the GPV Market}

In an attempt to reconcile attitudes regarding GPV system features, benefits, and barriers with stated intention to pursue GPV purchase, parallel analyses were conducted using the statistical technique of cluster analysis. A cluster analysis was conducted using the survey's attitudinal data in factor form, and a second cluster analysis was conducted using the survey's outcome variables. The two statistically satisfactory cluster solutions were then crosstabulated in an effort to identify the numbers of homeowners who not only say they would pursue GPV purchase but whose attitudes regarding GPV system features, benefits, and barriers are consistent with their stated intention.

\section{Size and Composition of the GPV Market}

The analyses indicate that $16 \%$ of the surveyed homeowners simultaneously occupy the two most conceptually receptive predictor clusters and the Highly Likely (to purchase GPV) criterion cluster. This $16 \%$ can be considered the core market for near-term GPV purchase because of the congruence of their receptive attitudes toward GPV and their stated intentions of pursuing GPV purchase.

When the projected "next-tier" customer groups were analyzed according to their hypothetical willingness to pay for GPV systems, it was found, not surprisingly, that as net system cost increases, willingness to pay (WTP) declines, especially beyond $\$ 50$ per month for either a $50 \%$ or a $100 \%$ GPV system. The size of the immediate market under the $100 \%$ system scenario at $\$ 100$ per month net cost is estimated to be a minimum of about 5,000 Colorado homeowners. At $\$ 125$ a month net increase in cost for a $100 \%$ PV system, the market size is estimated to be a minimum of about 1,300 homeowners.

\section{Conclusions and Recommendations}

A market for residential grid-tied PV systems exists in Colorado today. That market is substantial enough for companies to successfully market PV systems to Colorado homeowners. These systems will have to be custom-designed to fit varied customer needs and preferences and different architectural styles and roof surfaces.

In September 1999, Public Service Company offered its customers GPV systems that can be net metered in the price range of $\$ 8,000$ for a very small system to $\$ 45,000$ for a $100 \%$ system with emergency back-up. These costs are markedly higher than those used in this study to estimate market size in Colorado. Higher costs will slow market acceptance of GPV systems.

Without question, utility practices and government policies will affect the rapidity of GPV uptake, although a few homeowners will go ahead with GPV system purchase regardless of utility or government action. If the State of Colorado or the federal government were to implement substantial financial incentive policies to foster GPV adoption, the size of the potential market for PV residences would increase. Those interested in purchasing a PV system highly subsidized by the government — despite their political conservatism—comprise 
an estimated $6 \%$ of Colorado households living in single-family dwellings. Subsidized systems could be made available, for example, through systems benefits charges in connection with utility restructuring.

Aside from substantial legislative intervention on behalf of GPV, utilities will make or break this market. They (and by extension, their contractors) are not only an authoritative source of information about GPV, but they also control net metering policies (unless the state Public Utilities Commission decides to take a favorable and binding stand on net metering). Net metering appears to be one of the most crucial factors in providing financial advantages to homeowners adopting GPV. Many homeowners need to feel that they will break even financially at some point in the future - even if it is in the distant future - before they would purchase GPV. In addition, utilities could stimulate the GPV market by offering their customers financing for GPV system purchase - the means of paying for GPV that homeowners appear to prefer most.

Colorado's homeowners appear ready to learn more, inform themselves, and actively purchase GPV systems. The present situation is highly advantageous to Colorado's institutions - primarily its state government and its utility companies, and also its home builders - if they are ready to move forward on GPV technology. 


\section{Contents}

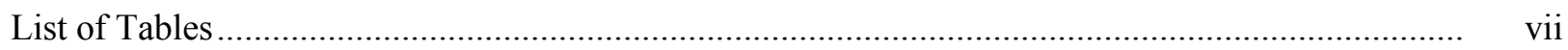

List of Figures.............................................................................................................. xi

Acknowledgments ...................................................................................................... xii

Executive Summary ...................................................................................................... xiv

Chapter 1. Introduction .....................................................................................................

Chapter 2. Guiding Ideas of the Study...........................................................................................

Literature Review ..................................................................................................

Rate of Adoption ......................................................................................................

Characteristics of Innovation Adopters............................................................................. 5

Innovation Attributes ................................................................................................... 6

Stages in the Adoption of Innovations............................................................................

"Next Tiers" ................................................................................................

Operationalizing the Model …………………………………………………………....

Study Hypotheses …………………………………………………………………... 10

Interpretation of Data............................................................................................... 12

Chapter 3. Descriptive Findings: Knowledge, Favorability, Benefits, Barriers,

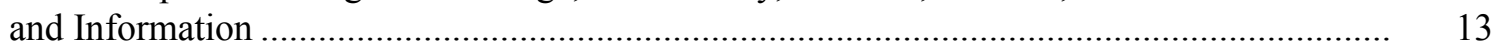

Familiarity and Favorability..................................................................................... 13

Knowledge and Behavioral Intention ............................................................................ 15

Perceived Benefits of GPV Adoption .............................................................................. 15

Perceived Barriers to GPV Adoption.............................................................................. 19

Information Needs ............................................................................................ 21

Information Sources............................................................................................ 23

Chapter 4. Descriptive Findings: Product Attributes …………………………………………….... 27

Preferred System Features …………………………………………………………….. 27

Preferred PV Suppliers …………………………………………………….... 29

Appearance/Performance Trade-offs .............................................................................. $\quad 30$

Excess Electricity and Net Metering............................................................................. 31

Chapter 5. Descriptive Findings: Willingness to Pay for GPV Systems and Favorability

Toward Using GPV ………………………………………................................. 34

System Size/Price Tradeoffs ........................................................................................ 34

Scenarios for GPV System Purchase .............................................................................. 35

Payment Preferences...................................................................................................... 43

Policy Preferences on GPV Subsidies .......................................................................... 44

Favorability toward Using GPV on One's Own Home …………………………………. 45

Changes in Favorability after Considering GPV Benefits and Costs.................................... 46 


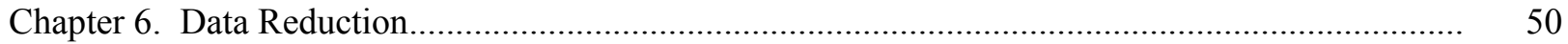

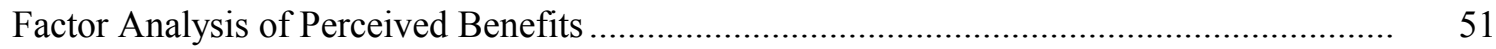

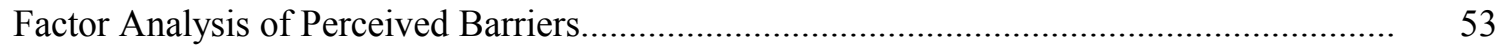

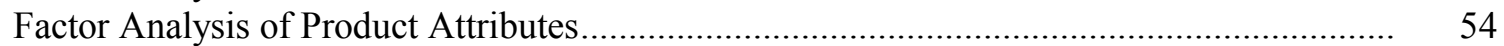

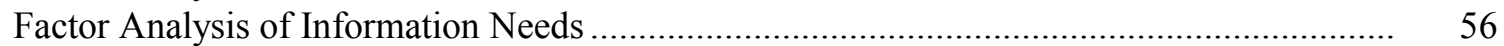

Factor Analysis of GPV Information Sources: Individuals, Groups, and Organizations ........ 57

Factor Analysis of GPV Information Sources: Channels.................................................... 59

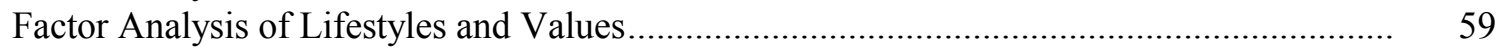

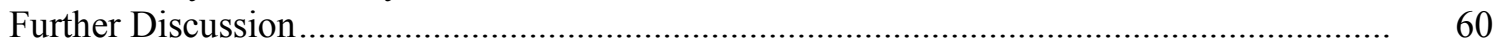

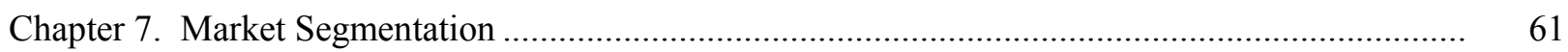

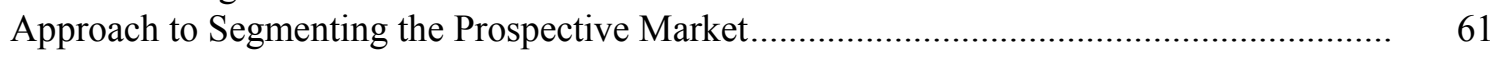

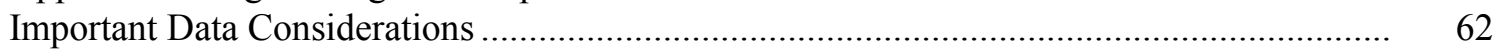

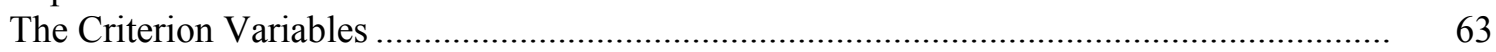

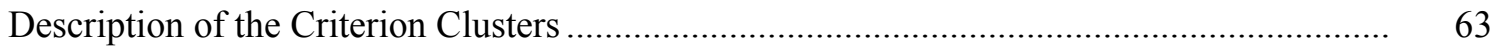

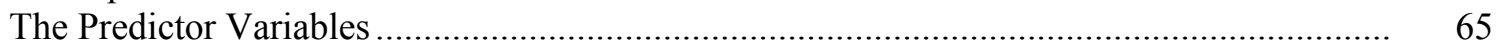

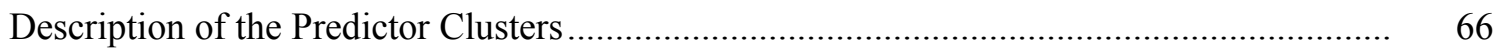

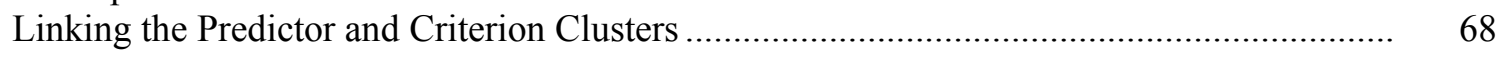

Establishing the Next Tiers of Market Development.......................................................... 71

Chapter 8. The Size and Composition of the GPV Market ...................................................... 75

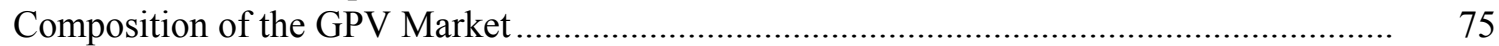

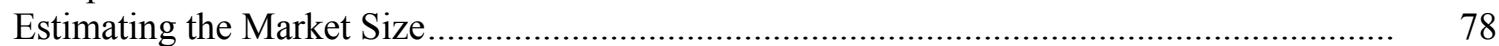

Market Sensitivity to System Size and Cost Trade-offs.................................................. 80

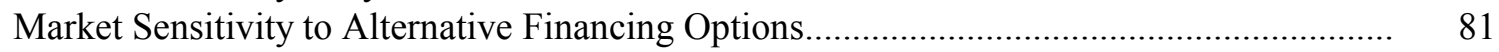

Market Response to Full Subsidization of Systems ............................................................

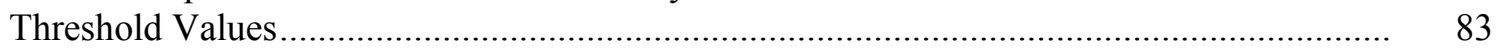

Chapter 9. Detailed Characteristics of Near-Term Purchasers................................................. 86

Two Types of Early Adopters of GPV ........................................................................ 86

A Comparison of Highly Likely (HL) Pacesetters and Highly Likely (HL)

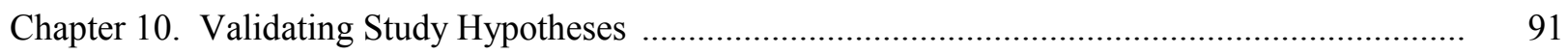

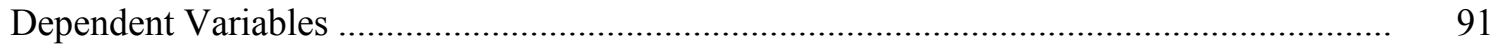

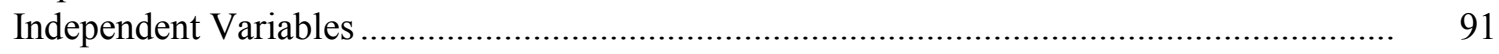

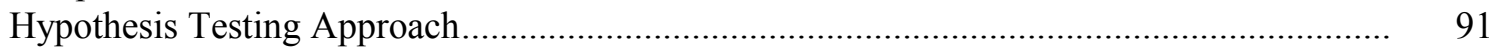

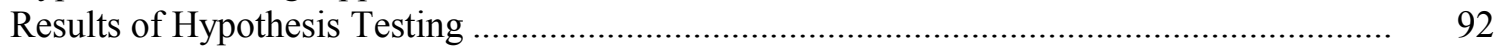

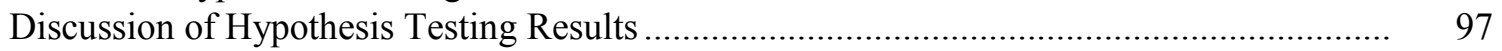

Chapter 11. Findings, Conclusions, and Discussion .................................................................. 101

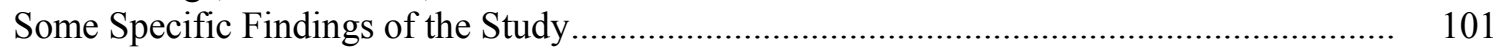

Caveats to Market Size Estimates ............................................................................... 102 


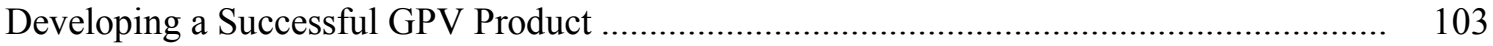

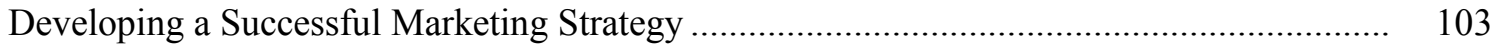

The Market Impacts of Institutional Intervention and Advocacy ..................................... 103

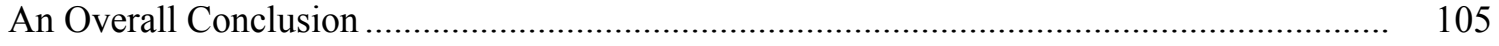

Chapter 12. Recommendations and Summary Remarks ........................................................... 106

PV System Marketers (Utility Companies, PV Manufacturers, and Homebuilders).............. 106

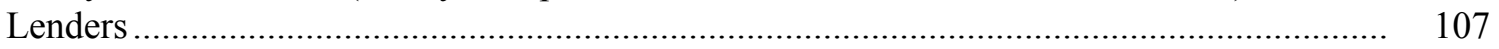

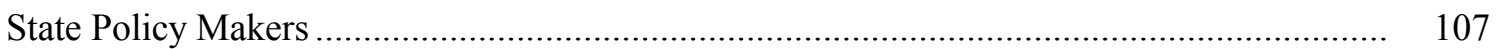

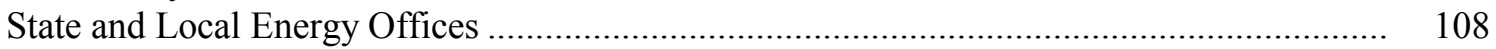

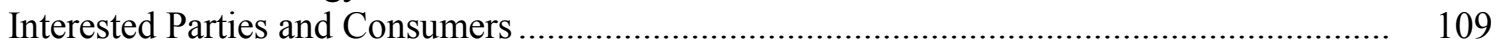

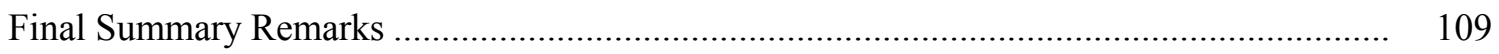

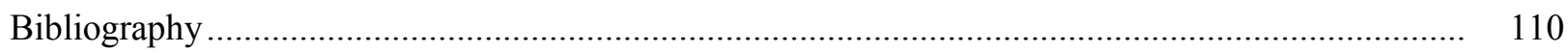

Appendixes

1. Respondent Characteristics (Demographics, Values and Lifestyles,

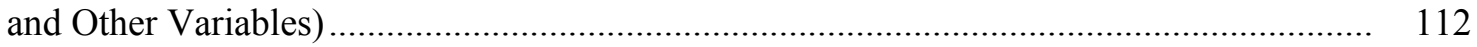

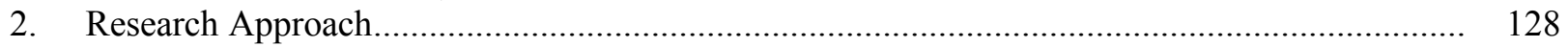

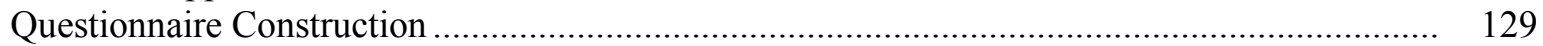

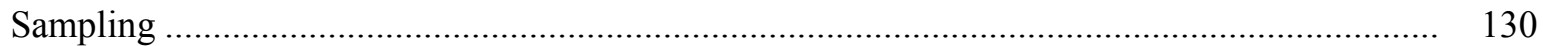

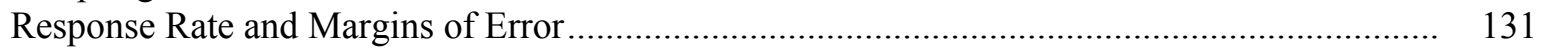

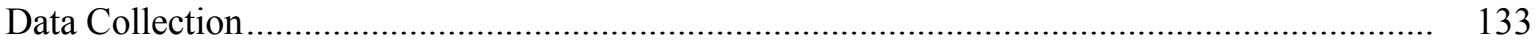

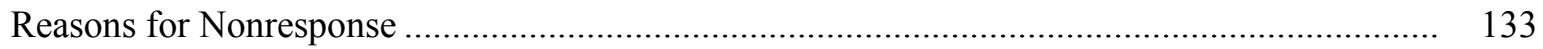

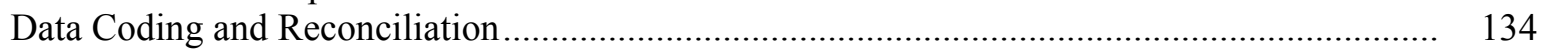

Representativeness of the Study's Respondents ........................................................... 135

Statistical Analysis ............................................................................................ 138

3. Base n's, Means, Standard Deviations, and Coefficients of Variation for Scaled Responses ...... 140

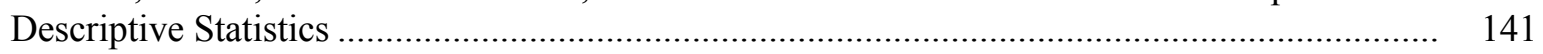

4. Detailed Factor Analysis Results ................................................................................ 149

5. "Positive" Response Patterns on All Study Variables Relative to Tier Membership................. 158

6. "Positive" Response Patterns on All Study Variables Relative to

Highly Likely Predictor Clusters .................................................................................. 171

7. Relationship of Cluster Matrix Membership and Membership in the Tiers to the

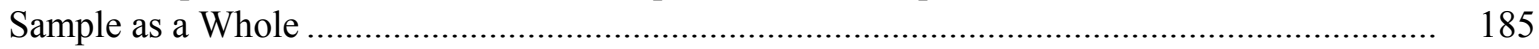

8. Experience with Efficiency and Renewables by Market Tiers ............................................. 191

9. Differences Between Highly Likely and Highly Unlikely Criterion Clusters on the Basis of Percentages of Highly Important Ratings Assigned to Relative

Advantages, Product Attributes, and Barriers.

J. Colorado Homeowner Questionnaire on Home-Based PV Systems Tied to the Utility Grid 


\section{List of Tables}

Page

\section{Guiding Ideas of the Study}

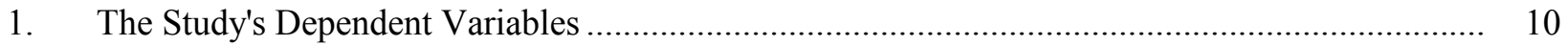

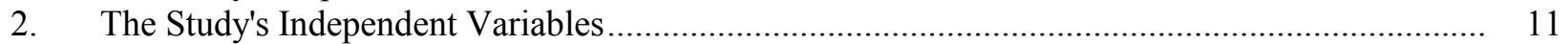

\section{Descriptive Findings: Knowledge, Favorability, Benefits, Barriers, and Information}

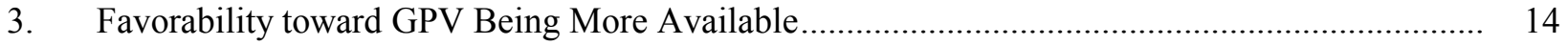

4. Perceived Sources of Electricity in Colorado...................................................................... 16

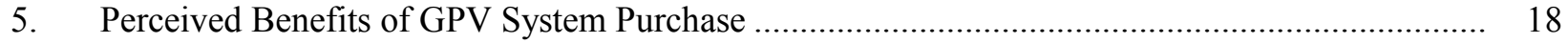

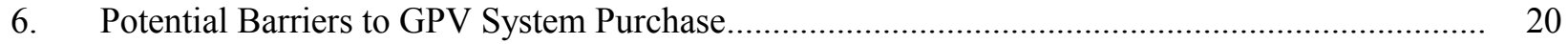

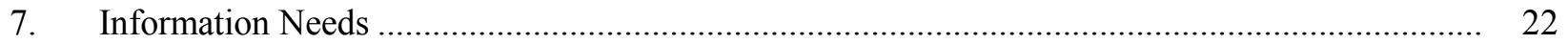

8. Individuals, Groups, and Organizations Preferred as PV Information Sources........................... 25

9. Preferred GPV Information Communication Channels............................................................. 26

\section{Descriptive Findings: Product Attributes}

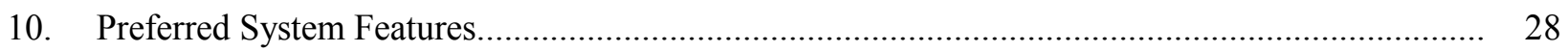

11. Preferred Source of GPV System Purchase ................................................................ 30

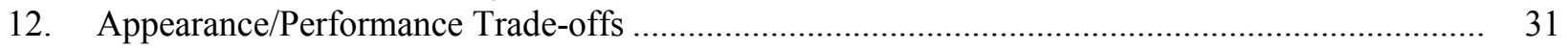

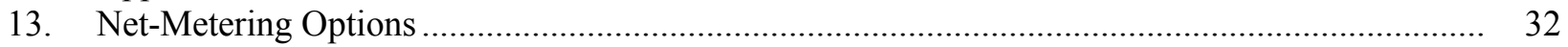

\section{Descriptive Findings: Willingness to Pay for GPV Systems and Favorability} to Using GPV

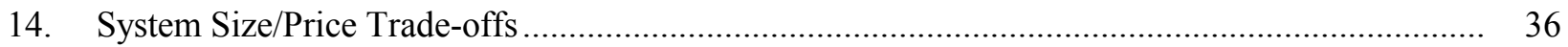

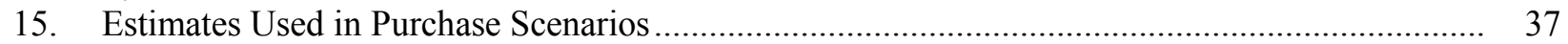

16. Net Amounts Willing to Pay More per Month for a Very Small GPV System ........................... 38

17. Net Amounts Willing to Pay More per Month for a Medium-Sized GPV System....................... 39

18. Net Amounts Willing to Pay More per Month for a Very Large GPV System ............................ 41

19. Likelihood of Purchase of a No-Added-Cost GPV System......................................................

20. Level of Choice (in Percent) by GPV Payment Options ............................................................

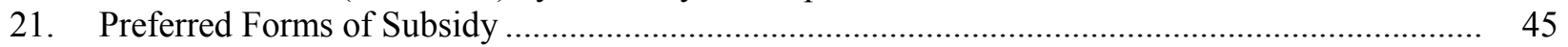

22. Favorability toward the Idea of Using PV on One's Own Home...............................................

23. Comparison of Responses on Favorability toward GPV ................................................... 48

24. Changes in Favorable Opinions toward GPV ............................................................. 49

\section{Market Segmentation}

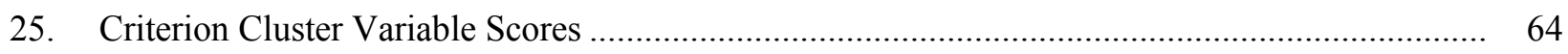

26. Percentage Allocation of Respondents to Criterion Clusters ................................................... 65

27. Factor Scores of Predictor Variable Clusters ......................................................................... 68 
28. Percentage Allocation of Respondents to Predictor Clusters, with

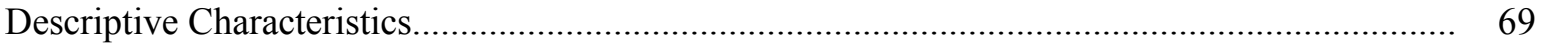

29. Predictor Cluster Membership in Criterion Clusters ..................................................... 70

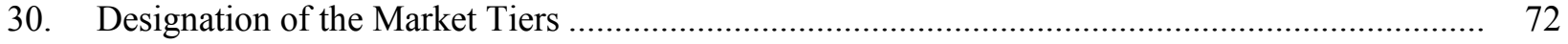

\section{The Size and Composition of the GPV Market}

31. Selected Demographic Characteristics of Respondents Included in the Tiers........................... 77

32. Values and Lifestyle Characteristics of Respondents Included in the Tiers................................. 78

33. Other Characteristics Related to GPV Adoption Exhibited by Respondents Included in the Tiers ............................................................................................

34. Low and High Market Size Estimates for Various System Sizes and Monthly Cost Alternatives

35. Low and High Market Size Estimates for Various Financing Options

\section{Detailed Characteristics of Near-Term Purchasers}

36. Comparative Responses of HL Pacesetters and HL Steady Positives Relative to

Selected Perceived Benefits

37. Comparative Responses of HL Pacesetters and HL Steady Positives to Selected Perceived Barriers

38. Comparative Responses of HL Pacesetters and HL Steady Positives Relative to Selected Product Attributes.

39. Comparative Responses of HL Pacesetters and HL Steady Positives Relative to Values and Lifestyles

\section{Validating Study Hypotheses}

40. The Study's Hypotheses and Results of Hypothesis Testing on

Attitudes, Knowledge, and Preferences

41. The Study's Hypotheses and Findings on Demographics.

\section{Appendix A: Respondent Characteristics (Demographics, Values, and Lifestyles, and Other Variables)}

A-1. Gender

A-2. Age

A-3. Marital Status

A-4. Annual Household Income before Taxes

A-5. Household Composition.

A-6. Rural or Urban Location .

A-7. Occupation

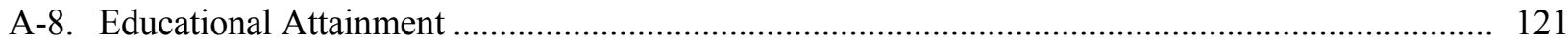

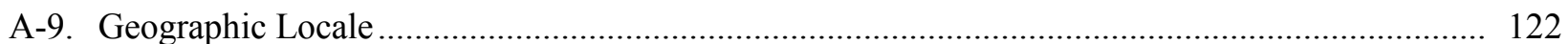

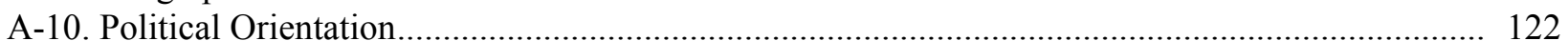




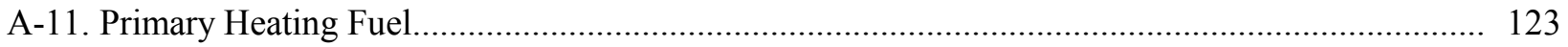

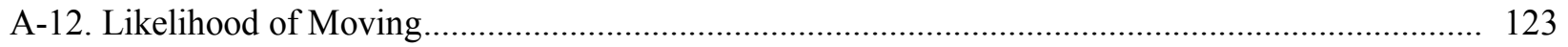

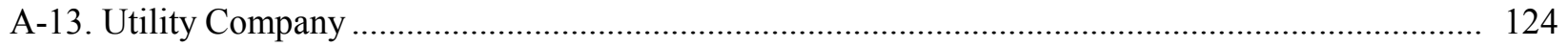

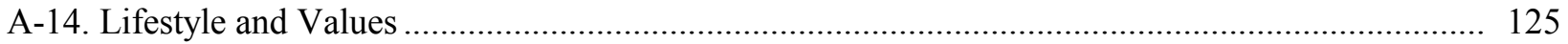

A-15. Experience with Efficiency and Renewables................................................................ 127

\section{Appendix B: Research Approach}

B-1. Margins of Error for Selected Dependent Variables .......................................................... 132

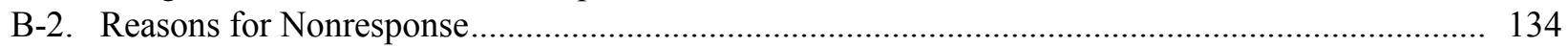

B-3. Comparison of Distributions of Percentages of Households Living in Various Geographic Areas of Colorado ..................................................................... 136

B-4. Comparison of Distributions of Percentages of Households Using Various Fuels as Their Primary Heating Sources ......................................................... 137

B-5. Comparison of Distributions of Percentages of Households Served by Various Utilities/Energy Providers.

\section{Appendix C: Base n's, Means, Standard Deviations, and Coefficients of} Variation for Scaled Responses

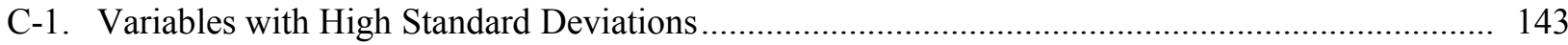

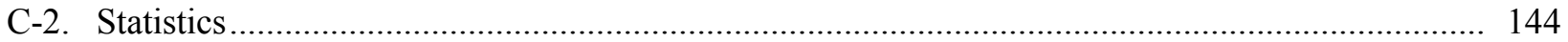

\section{Appendix D: Detailed Factor Analysis Results}

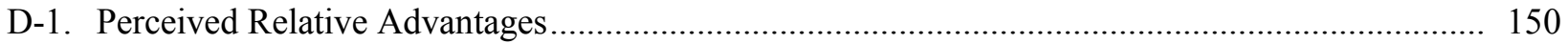

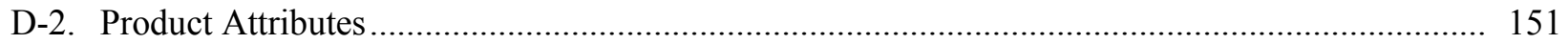

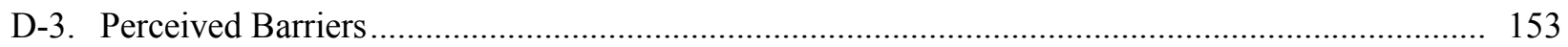

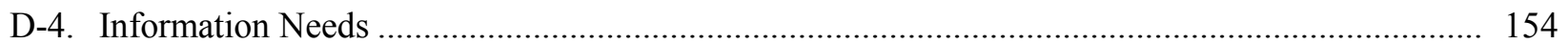

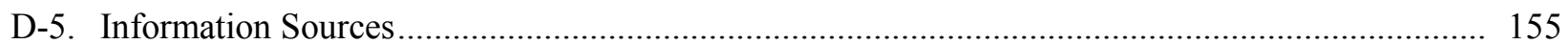

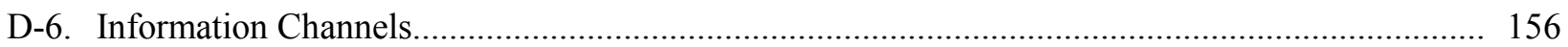

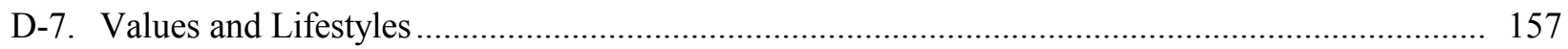

Appendix E: "Positive" Response Patterns on All Study Variables (Including Demographics) Relative to Tier Memberships

E-1. "Positive" Response Patterns on All Study Variables Relative to Tier Membership ................... 159

Appendix F: "Positive" Response Patterns on All Study Variables (Including Demographics) Relative to Highly Likely Predictor Clusters

F-1. "Positive" Response Patterns on All Study Variables Relative to Highly Likely Predictor Clusters. 
Appendix G: Relationship of Cluster Matrix Membership and Membership in the Tiers to the Sample as a Whole

G-1. Likelihood to Purchase a No-Added-Cost GPV System (Scenario D), Cluster Matrix Members versus Entire Sample

G-2. Likelihood of Looking for More Information on GPV

Cluster Matrix Members versus Entire Sample

G-3 System Size/Price Trade-offs, Cluster Matrix Members versus Entire Sample

G-4. Favorability toward Using GPV on One's Own Home,

Cluster Matrix Members versus Entire Sample

G-5. Likelihood to Purchase a No-Added-Cost GPV System (Scenario D), Members of Tiers versus Entire Sample

G-6. Likelihood of Looking for More Information on GPV, Members of Tiers versus Entire Sample

G-7. System Size/Price Trade-offs, Members of Tiers versus Entire Sample

G-8. Favorability toward Using GPV on One's Own Home, Members of Tiers versus Entire Sample

\section{Appendix H: Familiarity and Experience with Efficiency and Renewables of Respondents Assigned to the Different Market Tiers}

H-1. Nature of Experience with Energy Efficiency and Renewable Energy Equipment by Tiers

H-2. Familiarity with Energy Efficiency and Renewable Energy Equipment by Tiers

\section{Appendix I: Differences between Highly Likely and Highly Unlikely Criterion Clusters on the Basis of Percentages of Highly Important Ratings Assigned to Relative Advantages, Product Attributes, and Barriers}

I-1 Comparisons of Highly Likely and Highly Unlikely Criterion Clusters on the Basis of the Percentages of Respondents Rating Selected Relative

Advantages as Highly Important.

I-2. Comparisons of Highly Likely and Highly Unlikely Criterion Clusters on the Basis of the Percentages of Respondents Rating Selected Product

Attributes as Highly Important

I-3 Comparisons of Highly Likely and Highly Unlikely Criterion Clusters on the Basis of the Percentages of Respondents Rating Selected Barriers as

Highly Important. 


\section{List of Figures}

1. The Bell-Shaped Frequency Curve and the S-Shaped Cumulative

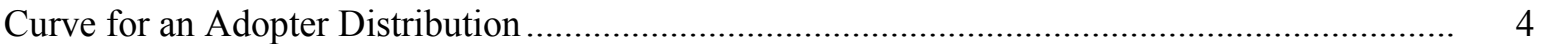

2. Examples of Diffusion Curves ............................................................................

3. Model of the Innovation-Adoption Decision Process ............................................................ 8

4. Net Incremental Monthly Amounts Respondents Are Willing to Pay for a Very Small GPV System (Cumulative).................................................................................................... 39

5. Net Incremental Monthly Amounts Respondents Are Willing to Pay for a Medium-Sized GPV System (Cumulative)

6. Net Incremental Monthly Amounts Respondents Are Willing to Pay for a Very Large GPV System (Cumulative)....

7. Initial Favorability toward Systems Being Available to Colorado Residents and Later Favorability toward the Idea of Using GPV on One's Own Home............................. 48

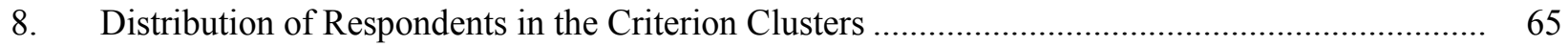

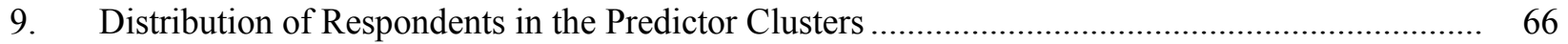

10. Percentage of Cluster Matrix Respondents in Tiers .................................................................

11. Percentages of Respondents in All Tiers Represented by Each Respective Tier ......................... 76

12. Estimate of Near-Term Market Size, Very Small GPV System ( $7 \%-15 \%$ of Electricity)

13. Estimate of Near-Term Market Size, Medium-sized GPV System (50\% of Electricity) .............. 84

14. Estimate of Near-Term Market Size, Very Large GPV System (100\% of Electricity).................. 85 


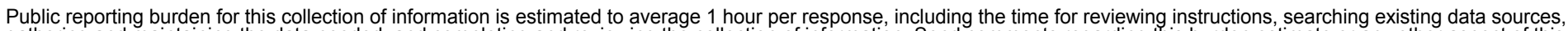

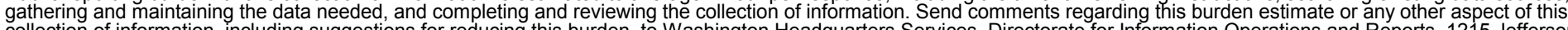

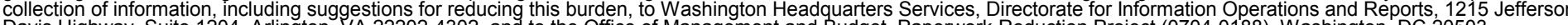
Davis Highway, Suite 1204, Arlington, VA 22202-4302, and to the Office of Management and Budget, Paperwork Reduction Project (0704-0188), Washington, DC 20503.
1. AGENCY USE ONLY (Leave blank)
2. REPORT DATE
September 2000
3. REPORT TYPE AND DATES COVERED
Technical Report

4. TITLE AND SUBTITLE

A Market Assessment of Residential Grid-Tied PV Systems in Colorado:

Executive Summary

6. $\operatorname{AUTHOR}(\mathrm{S})$

Barbara C. Farhar and Timothy C. Coburn

7. PERFORMING ORGANIZATION NAME(S) AND ADDRESS(ES)
5. FUNDING NUMBERS PV00.8201
8. PERFORMING ORGANIZATION REPORT NUMBER NREL/TP-550-28872

10. SPONSORING/MONITORING AGENCY REPORT NUMBER

National Renewable Energy Laboratory

1617 Cole Blvd.

Golden, CO 80401-3393

11. SUPPLEMENTARY NOTES

NREL Technical Monitor: NA

12a. DISTRIBUTION/AVAILABILITY STATEMENT

National Technical Information Service

12b. DISTRIBUTION CODE

U.S. Department of Commerce

5285 Port Royal Road

Springfield, VA 22161

13. ABSTRACT (Maximum 200 words)

This is the Executive Summary of a report that presents research done in response to a decision by the Colorado Governor's Office of Energy Conservation and Management (OEC) and Colorado utility companies to consider making residential gridtied photovoltaic (PV) systems available in Colorado. The idea was to locate homeowners willing to pay the costs of grid-tied PV (GPV) systems without batteries-\$8,000 or $\$ 12,000$ for a 2 - or 3-kilowatt (kW) system, respectively, in 1996 . These costs represented two-thirds of the actual installed cost of $\$ 6$ per watt at that time and assumed the remainder would be subsidized. The National Renewable Energy Laboratory (NREL) and OEC partnered to conduct a market assessment for GPV technology in Colorado. The study encompassed both qualitative and quantitative phases. The market assessment concluded that a market for residential GPV systems exists in Colorado today. That market is substantial enough for companies to successfully market PV systems to Colorado homeowners. These homeowners appear ready to learn more, inform themselves, and actively purchase GPV systems. The present situation is highly advantageous to Colorado's institutions-primarily its state government and its utility companies, and also its homebuilders-if they are ready to move forward on GPV technology.

14. SUBJECT TERMS

Market assessment; photovoltaics; grid-tied photovoltaics; residential systems

15. NUMBER OF PAGES

16. PRICE CODE

17. SECURITY CLASSIFICATION OF REPORT

Unclassified
18. SECURITY CLASSIFICATION OF THIS PAGE Unclassified
19. SECURITY CLASSIFICATION OF ABSTRACT Unclassified
20. LIMITATION OF ABSTRACT

UL 